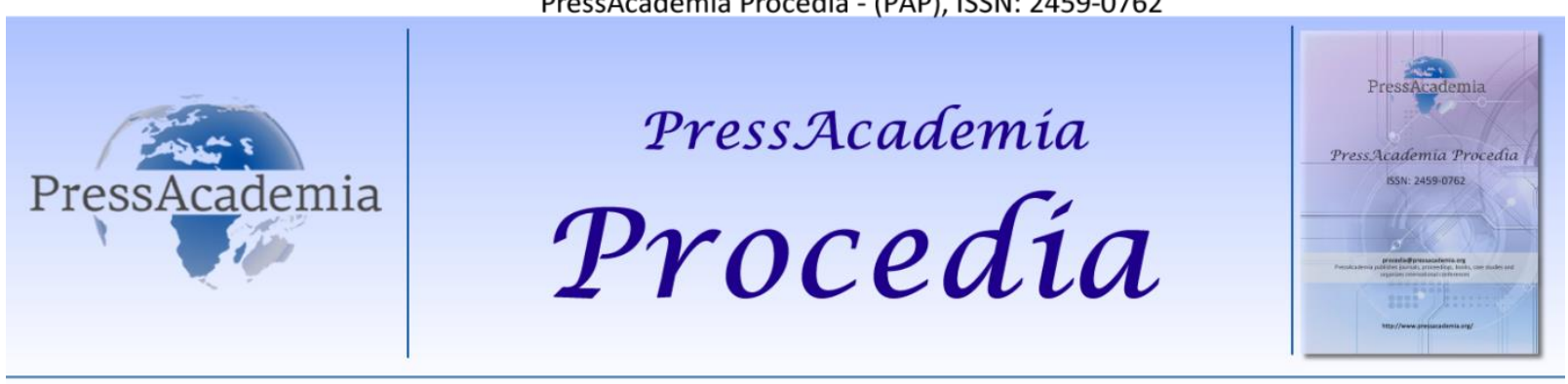

2nd World Conference on Technology, Innovation and Entrepreneurship

May 12-14, 2017, Istanbul, Turkey. Edited by Sefer Şener

\title{
THE CONNECTION CALCINATION AND SULPHATION WITH THE THERMAL BEHAVIOR OF CHALCOPYRITE ORE CONCENTRATE
}

\author{
DOI: 10.17261/Pressacademia.2016.592 \\ PAP-WCTIE-V.5-2017(30)-p.214-223 \\ Meltem Kizilca ${ }^{1}$, Mehmet Copur ${ }^{2}$ \\ ${ }^{1}$ Department of Chemical Engineering, Ataturk University, Erzurum, Turkey \\ ${ }^{2}$ Department of Chemical Engineering, Bursa Technical University, Bursa, Turkey. mkizilca@atauni.edu.tr
}

\section{ABSTRACT}

The thermal behavior of chalcopyrite ore concentrate was used thermogravimetric analysis (TG) coupled by differential thermal analysis (DTA). The thermal analysis were done up to $900^{\circ} \mathrm{C}$ from $0^{\circ} \mathrm{C}$ at different heating rates $\left(2,5,10,15\right.$ and $\left.20{ }^{\circ} \mathrm{C} / \mathrm{min}\right)$ under air atmosphere. The ore was calcined at 30,60, $90 \mathrm{~min}$ and $350,400,450,600$, and $800^{\circ} \mathrm{C}$ and investigated sulphation proportions. The products of obtained calcination were characterized by XRD, SEM/EDS, FTIR analysis. Based on the conclusions obtained was confirmed the thermal behavior of the ore.
\end{abstract}

Keywords: Chalcopyrite, thermal analysis, calcination, sulphation, characterization

\section{INTRODUCTION}

Copper, is one of the most important among industrial metals, has a wide use area in industry such as cooling and refrigeration tubing, electrical equipment, jewelry, electrical power cables, heat exchangers. It is present usually as metallic in small quantities, and mostly as sulphated minerals, oxidized minerals and complex minerals in nature. Chalcopyrite $\left(\mathrm{CuFeS}_{2}\right)$, a copper sulphide minerals, is the most exploited as primary sources of copper. But the dissolution of copper sulphide minerals is quite difficult (Parasad et al., 1999; Mikhlin et al., 2004). Such minerals need to be converted into sulphate in order to be converted into soluble structure. The transformation to the sulfate structure by preheating of the minerals in the sulfur structure is called roasting. There are three common roasting methods: chlorination roasting, oxidation roasting and sulfation roasting. In the chlorination roasting; for the formation of metal chlorides to metal sulphides are a type of roasting made by the addition of some chlorinating agent, chlorine gas or some chlorides. This methods is a threat to the environment due to released gas $\left(\mathrm{HCl}, \mathrm{Cl}_{2}\right)$ from the furnace. In oxidation roasting made of roasting at high temperature copper will cause a loss by creating copper ferrite. The sulfation roasting is an important route to recover copper from a copper sulphide minerals because during this process water-soluble sulphate and acid-soluble oxide compounds of copper are dissolved in the environment. At the same time, sulfur gas released during the roasting process ores with sulphide content are both stored and converted to sulfuric acid. It is known that due to its hazardous nature, $\mathrm{SO}_{2}$ is not environmentally friendly and harmful to health and difficult to handle. (Copur et al., 2015; Zhao et al., 2015). The ore is oxidized after roasting process. Chemical conversion reactions during roasting are utilized

to change the connection of the element to be recovered in metallurgy. Creating a technical possibility or going to a more economical work requires the application of such reactions. It is quite difficult to predict the reaction and mechanism of chalcopyrite ore, which is characterized as a complex mineral. This is mostly because of a few other reaction taking place with one another interlocutory products. Define an exclusive temperature range for a demand product is very important for the process. Additionally, take into account the complexity of the process, define the reaction sequence may be determined by using TG/ DTG (thermal analysis techniques). These techniques are very beneficial for comprehension and planning of phase transformations and the selectivity (Parasad et al., 1999). 
In the present work, the contribution of sulfation roasting for the recovery of copper from ore a copper sulfide content was investigated. As a contribution to the better knowledge of this process, reaction and mechanism of roasting process of chalcopyrite ore were determined the thermal analysis techniques (TG/ DTG). Supported with XRD-SEM-EDS-FTIR results of roasted products at selected temperatures.

\section{LITERATURE REVIEW}

Sargsyan and Hovhannisyan (2010a) were determined as the optimal roasting temperature $\left(650 \pm 10^{\circ} \mathrm{C}\right)$ and the roasting time (30 $\mathrm{min}$ ) with sulfating roasting chalcopyrite concentrates of distinct pyrite contents for the recovery of copper. Sargsyan and Hovhannisyan (2010b) determined using thermal analysis techniques (TG/ DTG) the phase transformations forms in chalcopyrite cuprum concentrate. They reported that $\mathrm{Cu}$-Fe-S transform into water-soluble sulphate phases at temperatures up to $676^{\circ} \mathrm{C}$ and into oxides when the temperature is greater than $676^{\circ} \mathrm{C}$. Jain et al. (1982) inspected the optimum temperature of roasting $\mathrm{CuFeS}_{2}$ ore for the optimum recovery of copper from $\mathrm{CuFeS}_{2}$ ore in $\mathrm{H}_{2} \mathrm{SO}_{4}$ solutions in a mullite tube furnace. They determined that they reached a maximum value of the copper concentration in owing to the formation of soluble sulfates at a temperature of $550^{\circ} \mathrm{C}$ and afterwards begins decrescenting due to the formation of insoluble ferrites. Parasad et al. (1988) studied using thermal analysis techniques (TG/ DTG) the phase transformations forms with of some additives such as $\mathrm{Fe}_{2} \mathrm{O}_{3}, \mathrm{Na}_{2} \mathrm{SO}$, FeSO4 to chalcopyrite ore. They display that these additives contributed to copper concentrate of the sulphation roasting at $773 \mathrm{~K}$. They determined that there was more sulphation with $\mathrm{Fe}_{2} \mathrm{O}_{3}, \mathrm{Na}_{2} \mathrm{SO} 4$, and $\mathrm{FeSO} 4$ than without any addition. Gülfen and Aydın, 2010 were studied calcination of chalcopyrite ore with $\mathrm{Fe}_{2} \mathrm{O}_{3}$ as sulfation agent and without any agent addition. They were found that $\mathrm{Fe}_{2} \mathrm{O}_{3}$ addition contributed more copper sulphate conversion and as the optimal roasting temperature (873K) and the roasting time (60 min). Zhao et al. (2015) were studied sulfation roasting with $\mathrm{Na}_{2} \mathrm{SO}_{3}$ as sulfation agent and without any agent addition to recover copper from the $\mathrm{CuFeS}_{2}$ concentrate. They were determined as the optimal roasting temperature $\left(500^{\circ} \mathrm{C}-550^{\circ} \mathrm{C}\right)$ and the roasting time (1200 $\mathrm{min})$.

\section{METHODOLOGY AND DATA}

The chalcopyrite ore was from the Rize Çayeli of Turkey. The chemical analysis of the concentrate for $63 \mu \mathrm{m}$ sieve is dedicated in Table 1.Mineralogical analysis of the concentrate was implemented using XRD (X-ray diffraction) (Bruker D8 Advance) powder diffraction. The results are shown in Fig. 1. $\mathrm{CuFeS}_{2}$ and $\mathrm{FeS}_{2}$ are a large amount of and other compounds such as $\mathrm{ZnS}, \mathrm{Cu}_{2} \mathrm{~S}$ are smaller amounts of in the sample. In addition, SEM (energy dispersive X-ray spectroscopy) and EDS (energy dispersive $\mathrm{X}$-ray spectroscopy), which combines surface microstruture and elemental compound of the chalcopyrite ore was defined by using X-MaxN attached to a JEOL 6010 LV Oxford Instruments in Fig. 2. The EDS analysis shows $\mathrm{O}, \mathrm{Fe}, \mathrm{Cu}, \mathrm{Al}, \mathrm{Zn}, \mathrm{Si}, \mathrm{S}$, and $\mathrm{Pb}$. (The percentage ratios of the elements: $1.21,23.77,26.54,1.55,0.17,0.22,22.34$ and $\mathrm{Pb}-24.20$, respectively).

Table 1: The Chemical Analysis of Chalcopyrite Ore

\begin{tabular}{lccccc}
\hline Element & $\mathrm{Cu}$ & $\mathrm{Fe}$ & $\mathrm{S}$ & $\mathrm{Zn}$ & $\mathrm{Pb}$ \\
\hline Percent (\%) & 24.88 & 29.46 & 34.23 & 2.19 & 1.19 \\
\hline
\end{tabular}

Figure 1: XRD Recordings of Chalcopyrite Concentrate

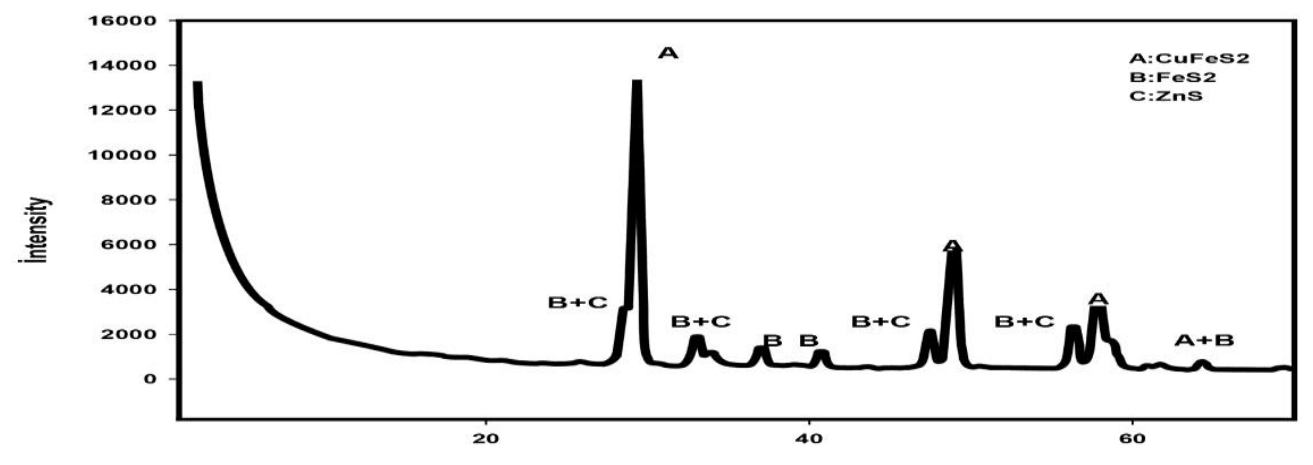




\section{Theta /degree}

The thermal analysis were performed using NETZSCH STA 409 PC Luxx instrument. The ore samples of 15-20 mg were used and Measurements carried out in air atmosphere at 2, 5, 10, 15 and $20 \mathrm{~K} / \mathrm{min}$ heating rates at 298-1173 K. FTIR spectrum was recorded to identify the chemical structure of the ore using Perkin Elmer spectrometer 100 in Fig. 3 . The peak $480 \mathrm{~cm}^{-}$ ${ }^{1}$ and $600 \mathrm{~cm}^{-1}$ are FeS bands at, $612 \mathrm{~cm}^{-1}$ is ZnS bands, the peaks at $1390-1290 \mathrm{~cm}^{-1}$ are asymmetric stretching of $(\mathrm{S}-\mathrm{O})$ and the peaks at $1190-1120 \mathrm{~cm}^{-1}$ are symmetric stretching of (S-O) in Fig. 3.

\section{Figure 2: SEM Image of Chalcopyrite Core and EDS Pattern (inset)}

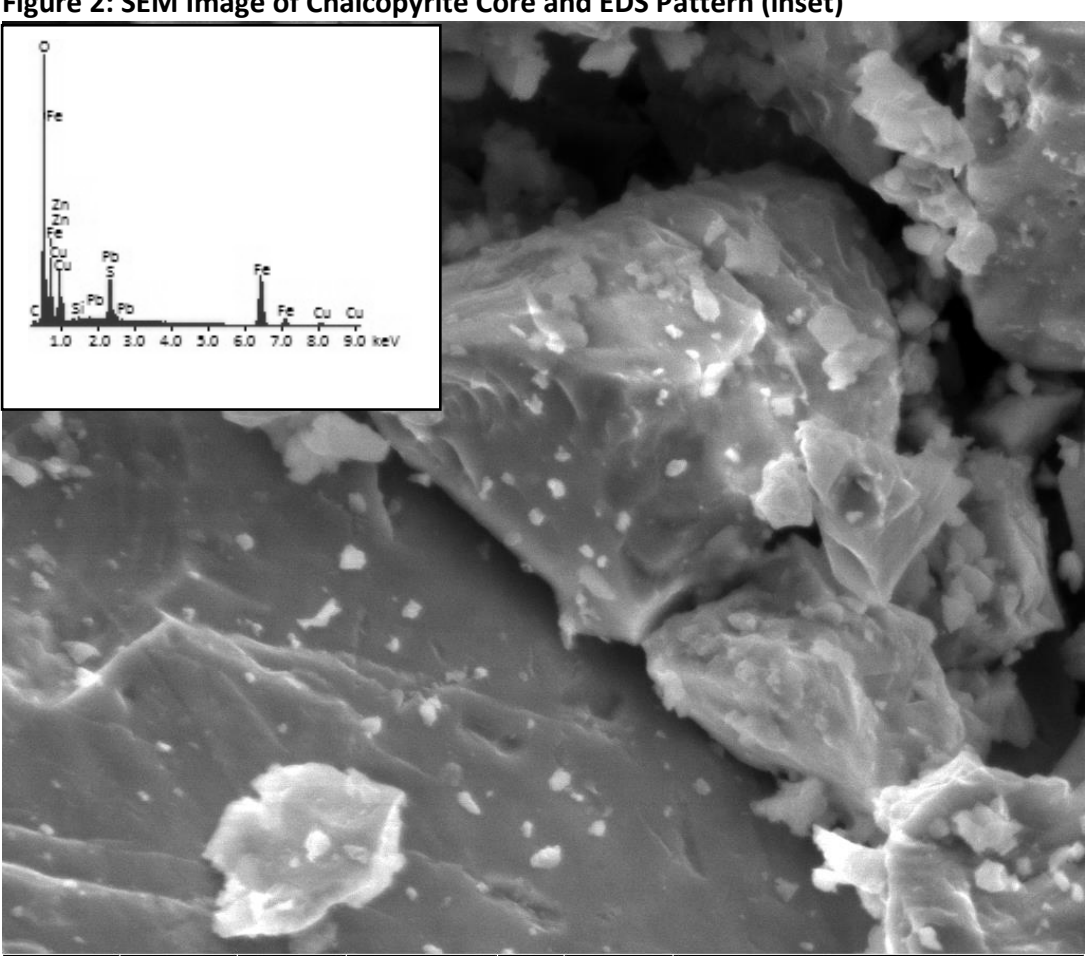

Figure 3: FT-IR Spectrum of Chalcopyrite Ore

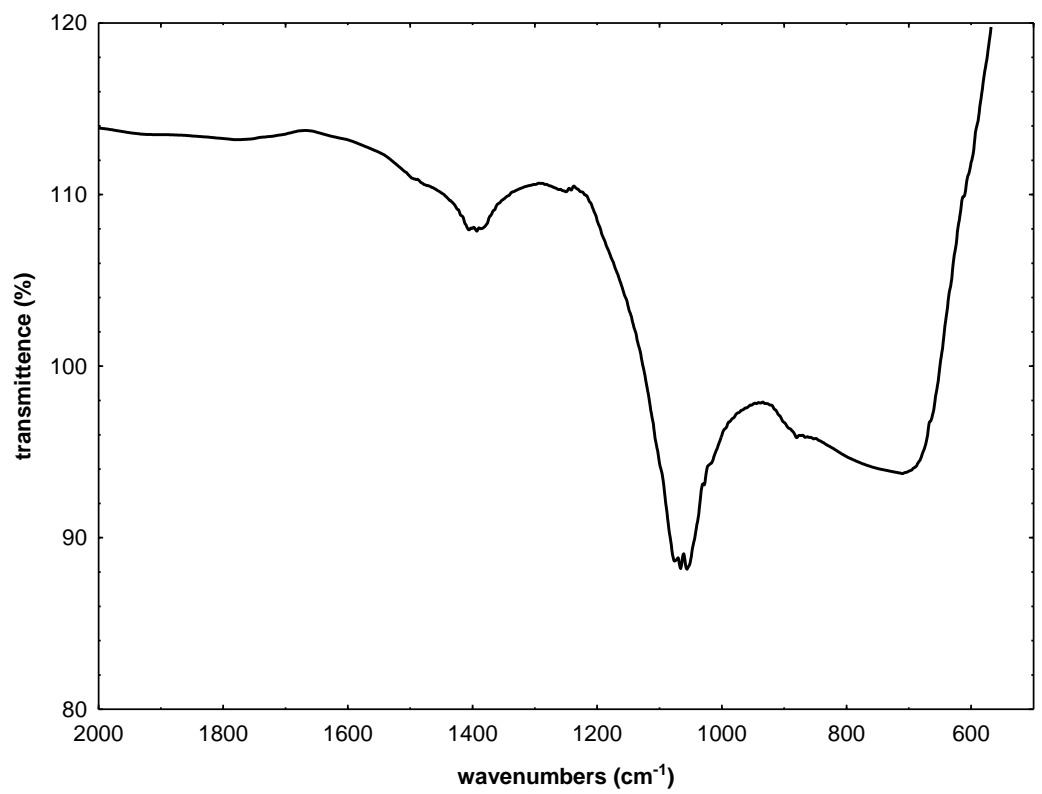


The roasting process was performed on a porcelain capsules at 30,60, 90 min and 350,400,450, 600, and $800^{\circ} \mathrm{C}$ in an ash oven at a rate of $60 \mathrm{~cm}^{3} \mathrm{~min}^{-1}$ under the flow of air. Afterwards these roasted chalcopyrite patterns were weighed (in Table 2). XRD-SEM-EDS-FTIR results were applied to the samples obtained in the roasting experiments at selected temperatures.

Table 2: Mass Changes in Roasting of Chalcopyrite Ore

\begin{tabular}{cccccc}
\hline \multirow{2}{*}{ Roasting time (min.) } & \multicolumn{5}{c}{ Roasting temperature (g) } \\
\hline & $623 \mathrm{~K}$ & $673 \mathrm{~K}$ & $723 \mathrm{~K}$ & $873 \mathrm{~K}$ & $1073 \mathrm{~K}$ \\
\hline 30 & $-1,2$ & $-0,9$ & 4,13 & $-6,42$ & $-24,33$ \\
60 & -1 & $-0,93$ & 4,34 & $-6,12$ & $-24,09$ \\
90 & $-1,6$ & $-1,3$ & 4,44 & $-7,42$ & $-22,45$ \\
\hline
\end{tabular}

\section{FINDINGS AND DISCUSSIONS}

The roasting process was carried $350,400,450,600$, and $800^{\circ} \mathrm{C}$. The differences in mass amounts depending on the effect of roasting temperature are shown in the Fig. 4. In the roasting of chalcopyrite ore, weight changes that occur during calcination are shown in Table 2 and Fig. 4. Based on weight changes resulting from roasting the chalcopyrite ore, an increase was observed up to $723 \mathrm{~K}$. At $723 \mathrm{~K}$, a weight change of $4 \%$ was not significant.

Figure 4: Effect of Roasting Temperature

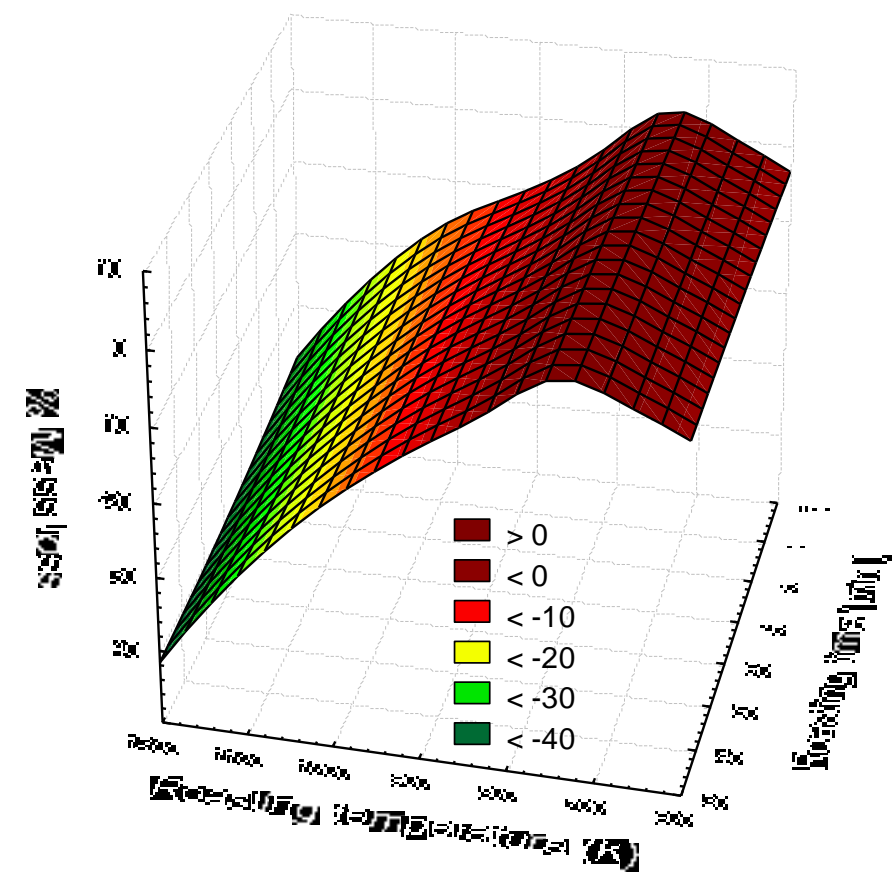

At $873 \mathrm{~K}$, a substantial change in mass did not occur, but there was a considerable mass loss (24\%) observed at $1073 \mathrm{~K}$. Above $723 \mathrm{~K}$, a weight increase occurred from the formation of sulfate compounds; at temperatures much higher than $723 \mathrm{~K}$, the weight decreased because of the degradation of sulfate compounds and decomposition of sulphide components in the chalcopyrite ore. Because the sulfate compounds formed readily dissolve in a leach environment. The optimal roasting temperature was achieved at $500{ }^{\circ} \mathrm{C}$. Also, thermal studies (DTA-TGA) were utilized to observe the transformation phases of chalcopyrite to copper sulfate. The overall graphs of DTA-TGA curves of chalcopyrite ore are shown in Figs. 5 and 6. With increasing heating rates from $2 \mathrm{~K} / \mathrm{min}$ to $20 \mathrm{~K} / \mathrm{min}$, DTA curves recorded at different heating rates have similar patterns although peaks usually change at elevated temperatures. 
Figure 5: TG Analysis of Chalcopyrite Ore

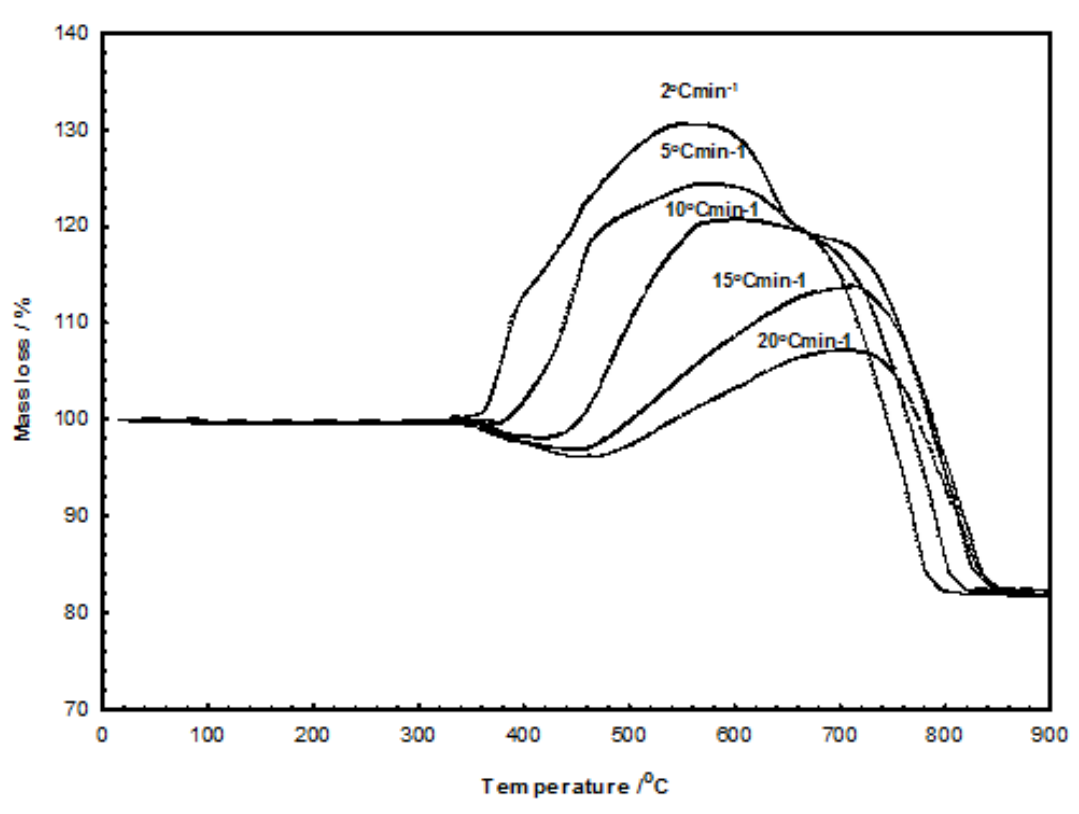

Figure 6: DTG Analysis of Chalcopyrite Ore

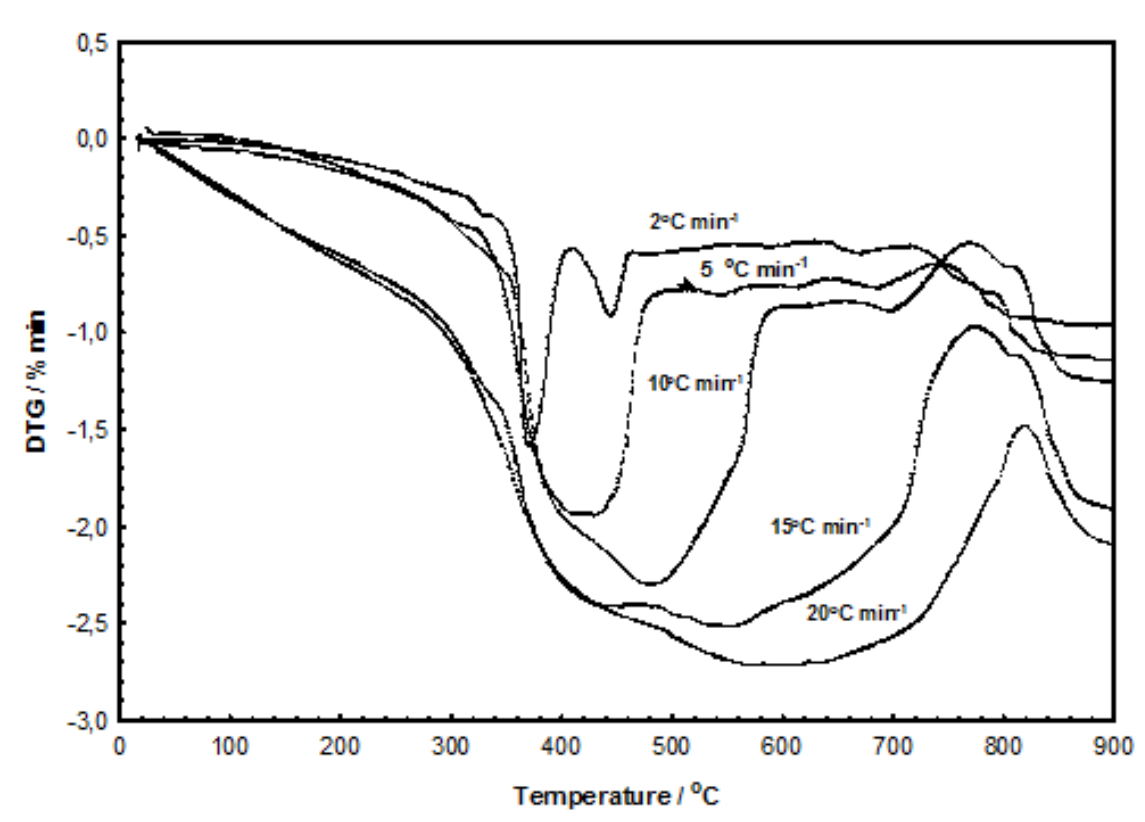

Furthermore, each DTA curve has two parts. The first part includes three exothermic peaks corresponding to oxidation of sulfides at low temperatures, whereas the second part includes endothermic peaks corresponding to the decomposition of previously formed sulfate and copper oxide-sulfate compounds. Figs. 4 and 5 reveal that the oxidation of chalcopyrite on its surface layer occurred at temperatures between $320^{\circ} \mathrm{C}$ and $360^{\circ} \mathrm{C}$, depending on heating rates. A substantial increase is not observed in TGA curves at these temperatures, whereas small-scaled exothermic peaks are seen in DTA curves. At this temperature, copper matte a mixture of $\mathrm{Cu}_{2} \mathrm{~S}$ and FeS is obtained. The reaction, as stated by Sokic et al. (2008), can be represented by the following equation: 
$2 \mathrm{CuFeS}_{2}+\mathrm{O}_{2}(\mathrm{~g}) \rightarrow \mathrm{Cu}_{2} \mathrm{~S}+2 \mathrm{FeS}+\mathrm{SO}_{2}(\mathrm{~g})$

Resulting from intense oxidation of the inner layer of chalcopyrite and simultaneous degradation of pyrite in the sample at temperatures between $370^{\circ} \mathrm{C}$ and $400{ }^{\circ} \mathrm{C}$, a high-intensity exothermic peak is clearly observed in the DTA curves. At this stage of the process, the formation of elemental sulfides decreased the amount of the original material.

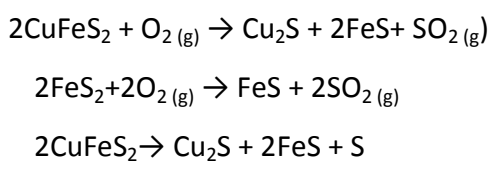

In subsequent heating operations, the weight of the sample increases and a moderate-intensity exothermic peak forms in DTA curves in the temperature range $420^{\circ} \mathrm{C}$ to $520^{\circ} \mathrm{C}$. At this stage of the roasting operations, iron sulfate, copper sulfate, and copper oxide-sulfate compounds form. With further increases in temperature, based on the TGA curves, the weight of the sample decreases by small amounts resulting from the degradation of iron sulfates; in DTA curves, unclear endothermic peaks form in the temperature range $525^{\circ} \mathrm{C}$ to $580^{\circ} \mathrm{C}$.

$2 \mathrm{FeSO}_{4} \rightarrow \mathrm{Fe}_{2} \mathrm{O}_{3}+\mathrm{SO}_{2}(\mathrm{~g})+\mathrm{SO}_{3}(\mathrm{~g})$

Sulfates start to degrade at temperatures above $700{ }^{\circ} \mathrm{C}$.

$\mathrm{CuSO}_{4} \rightarrow \mathrm{CuO}+\mathrm{SO}_{3}(\mathrm{~g})$

$\mathrm{CuO} \cdot \mathrm{CuSO}_{4} \rightarrow 2 \mathrm{CuO}+\mathrm{SO}_{3}(\mathrm{~g})$

At these temperatures, weight loss is observed in the TGA curves, and two endothermic peaks are seen in the DTA curves. At a heating rate of $2 \mathrm{~K} / \mathrm{min}$, peaks representing the degradation of copper sulfate and copper oxysulfate are observed at temperatures of $725{ }^{\circ} \mathrm{C}$ and $710{ }^{\circ} \mathrm{C}$. As heating rates are increased, copper sulfate and copper oxide sulfate begin to increase simultaneously at some stages; therefore, the peaks overlap. Prasad et al. (1999) indicated that during the roasting of chalcopyrite in air, the oxidation mechanism first results in formation of $\mathrm{Cu}_{2} \mathrm{~S}$ and FeS. Subsequently, $\mathrm{Cu}_{2} \mathrm{~S}$ transforms into $\mathrm{Cu}_{2} \mathrm{O}$, followed by the $\mathrm{CuO}^{-\mathrm{CuSO}_{4}}$ transformation. Finally, CuO.CuSO ${ }_{4}$ transforms into $\mathrm{CuSO}_{4}$. According to these authors, the oxidation process of chalcopyrite follows the path shown below.

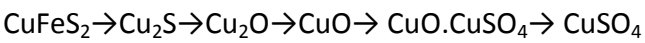

XRD recordings of the patterns of roasted chalcopyrite at 500, 600 and $700^{\circ} \mathrm{C}$ are showed in Fig. 7. In Fig. 7 is shown XRD recordings of patterns of roasted chalcopyrite at 500,600 and $700^{\circ} \mathrm{C}$. Remarkably, the existence of iron and copper in different types of sulfates and sulfides can be seen: $\mathrm{CuSO} 4, \mathrm{FeSO} 4, \mathrm{FeS}$ at $500^{\circ} \mathrm{C}$ and $600^{\circ} \mathrm{C}$.

Figure 7: XRD Recordings of Chalcopyrite Ore for 500,600 and $700^{\circ} \mathrm{C}$

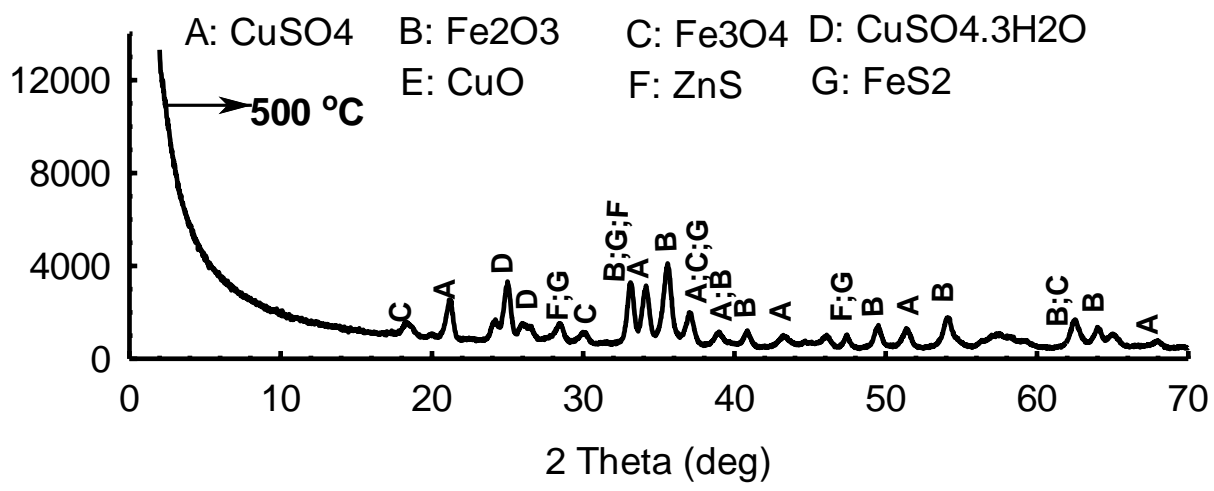




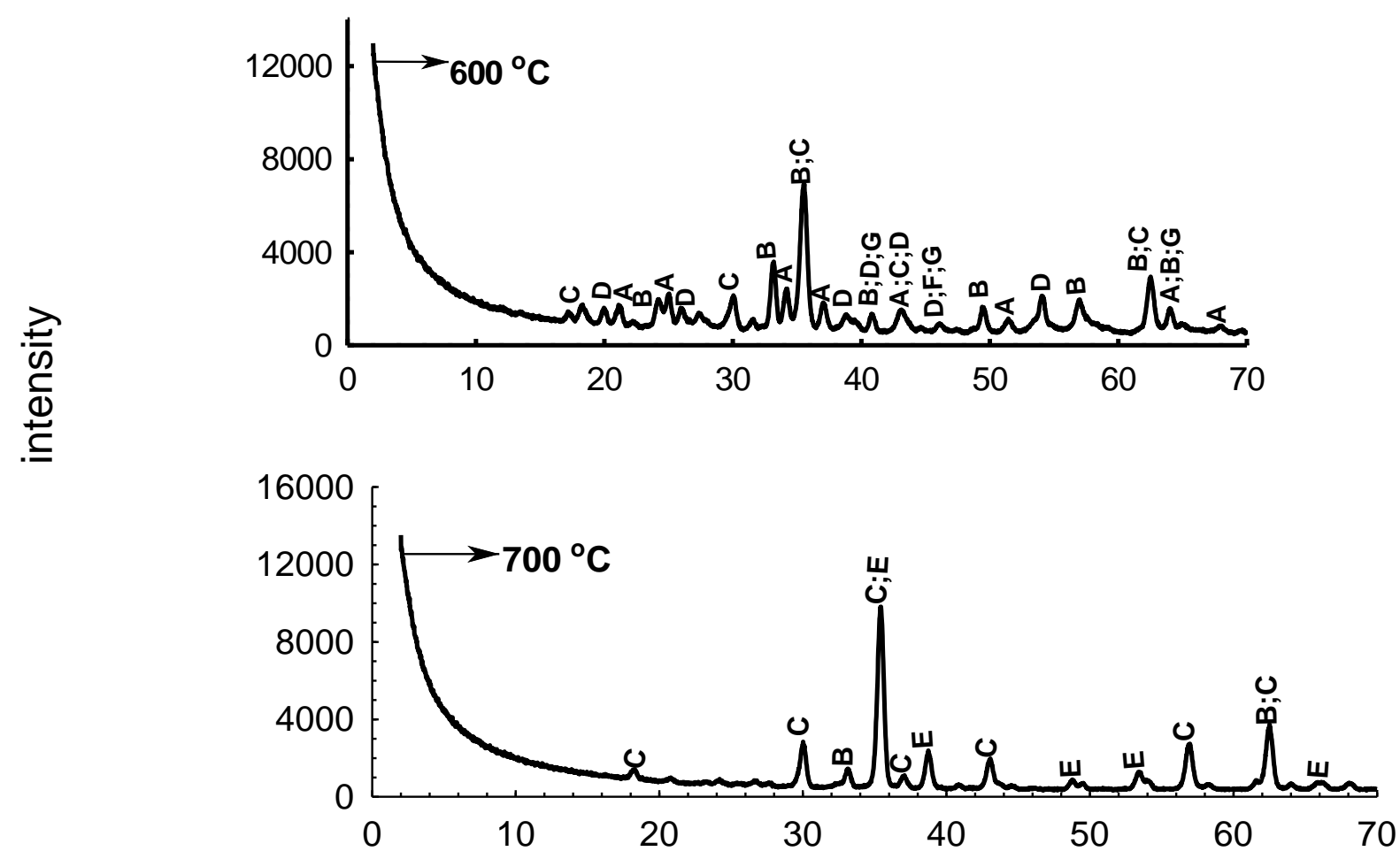

Furthermore, SEM (the surface microstructure) - EDS( the contents of the elements) techniques indicated that there are $\mathrm{O}$, $\mathrm{S}, \mathrm{Fe}$, and $\mathrm{Cu}$ in Fig.8 (The percentage ratios of the elements: 36.33, 10.37, 25.70 and 23,12, respectively) and $\mathrm{O}, \mathrm{S}, \mathrm{Fe}$ and $\mathrm{Cu}$ in Fig. 9 (The percentage ratios of the elements: 20.76, 3.55, 49.63 and 11.90, respectively). It involving $\mathrm{Fe}_{2} \mathrm{O}_{3}$ and $\mathrm{CuO}$ as final products at $700^{\circ} \mathrm{C}$ and SEM - EDS techniques indicated that there are O, S, Fe and Cu in Fig. 10 (The percentage ratios of the elements: $22.97,0.32,23.72$ and 42.46 , respectively). 
a)

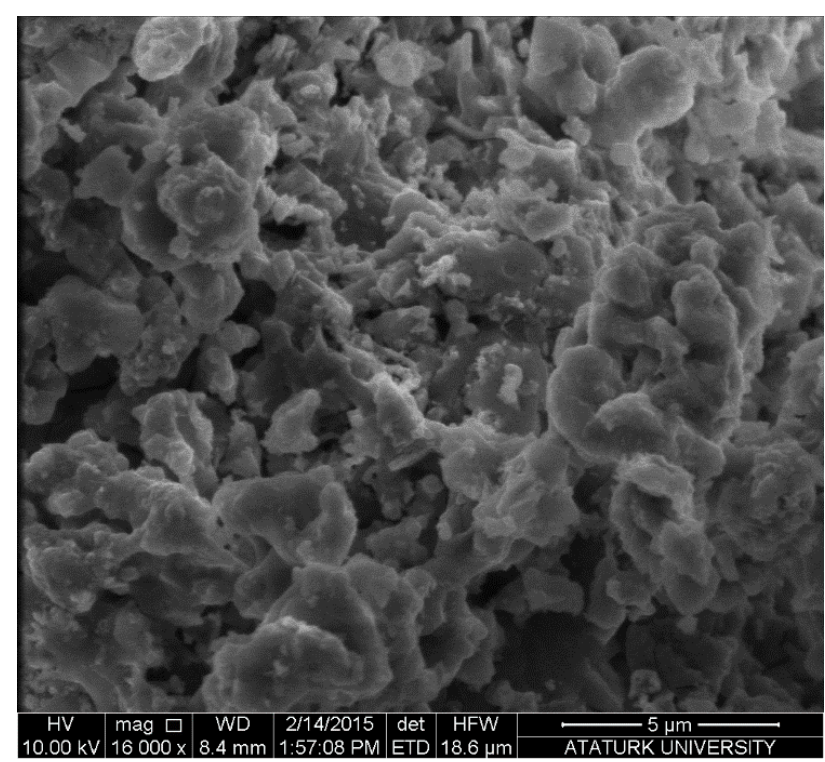

b)

Figure 8: SEM Images of Chalcopyrite Ore for $500^{\circ} \mathrm{C}(\mathrm{a})$ and EDS Pattern (b)

a)

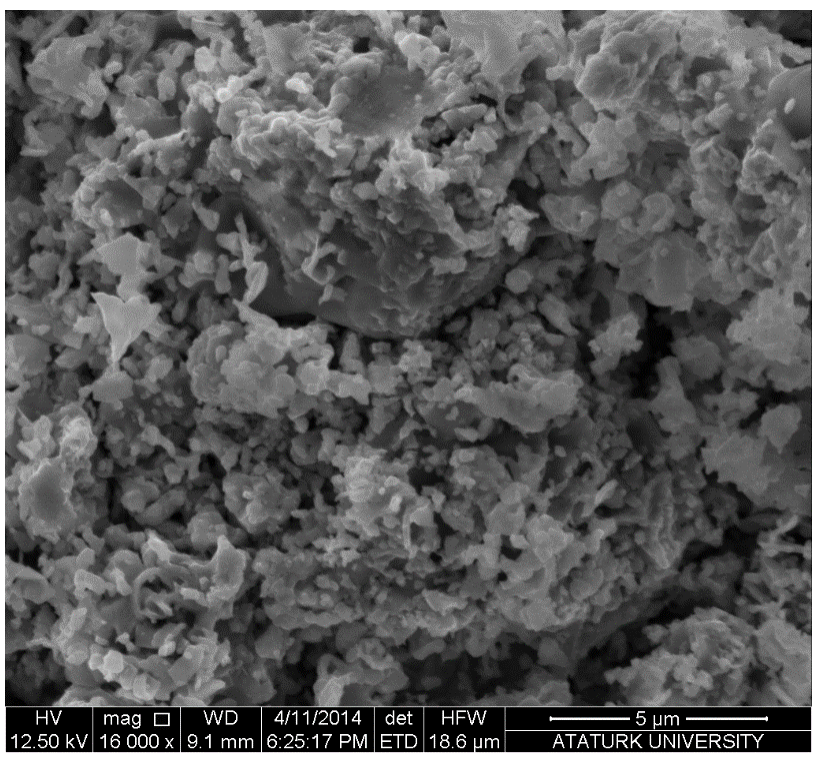

b)

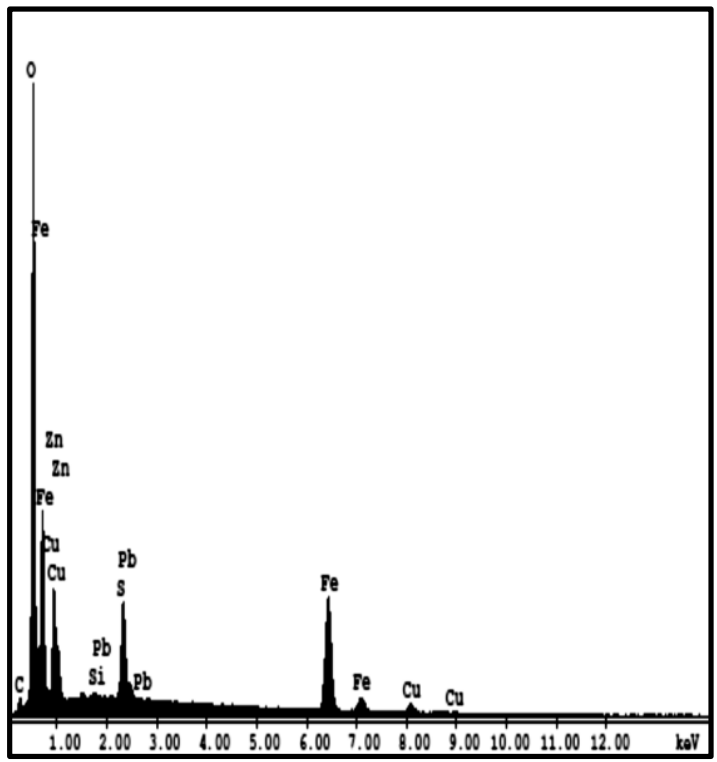

Figure 9: SEM Images of Chalcopyrite Ore for $600^{\circ} \mathrm{C}(\mathrm{a})$ and EDS Pattern (b) 
a)

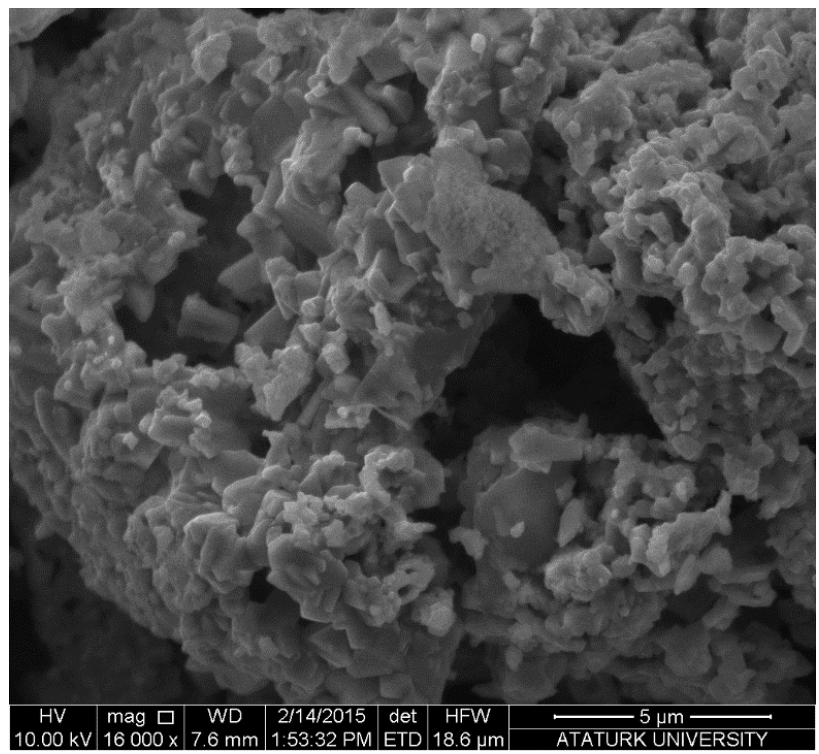

b)

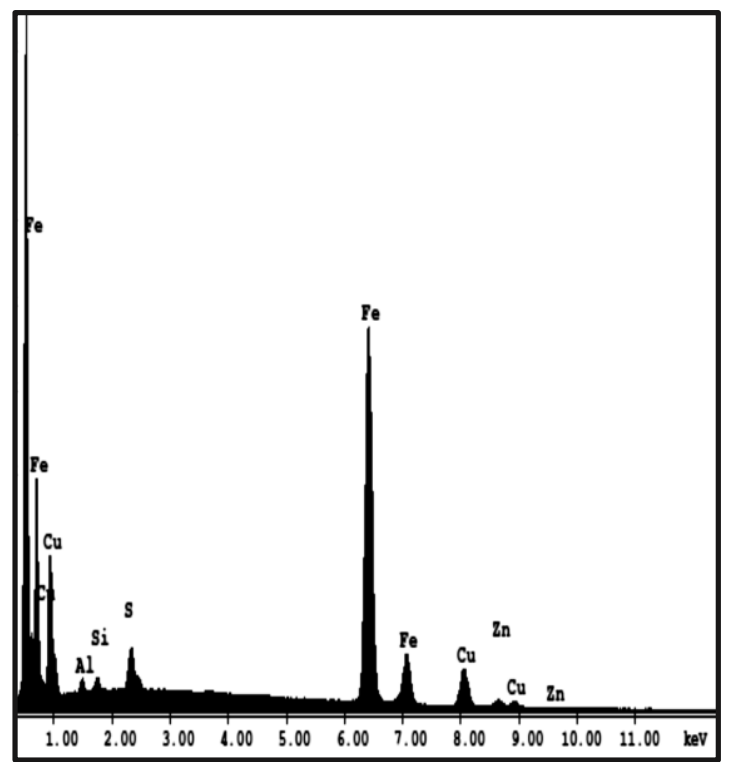

Figure 10: SEM Images of Chalcopyrite Ore for $700^{\circ} \mathrm{C}(\mathrm{a})$ and EDS Pattern (b)

Besides, FT-IR results confirmed these results. (Fig.11). The strong peak (S-O bands) at $1190-1120 \mathrm{~cm}^{-1}$ and $1390-1290 \mathrm{~cm}^{-1}$ confirmed the presence of sulfates and sulfides. Also, the peaks at $525 \mathrm{~cm}^{-1}$ and $580 \mathrm{~cm}^{-1}$ demonstrated the presence of $\mathrm{CuO}$ at $462 \mathrm{~cm}^{-1}$ and $560 \mathrm{~cm}^{-1}$ the presence of Fe2O3 (Rahman et. al., 2011; Suan et. al., 2011). The sulfation results chalcopyrite samples calcined at $400-900{ }^{\circ} \mathrm{C}$ are shown in Fig.11.

a)

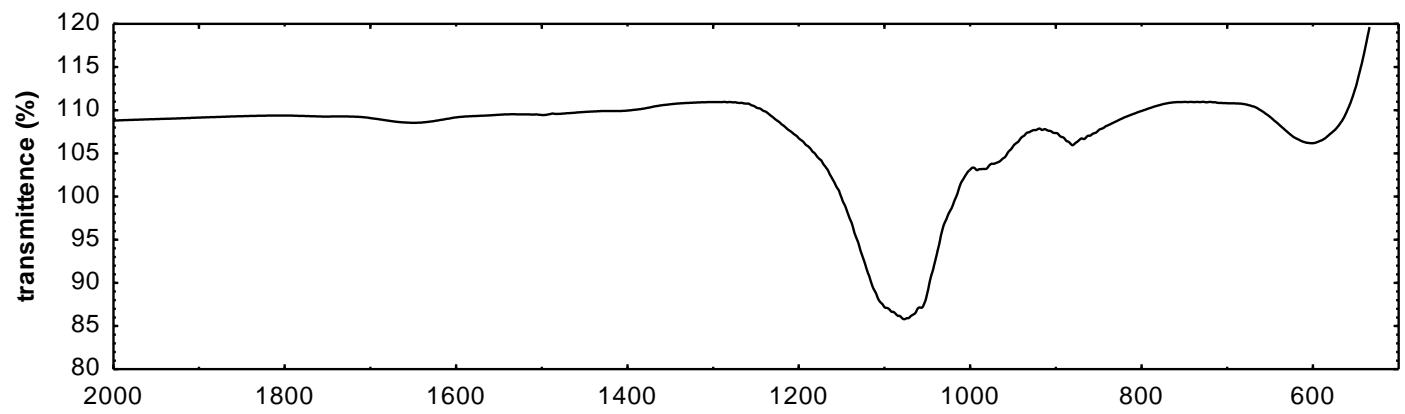

b)

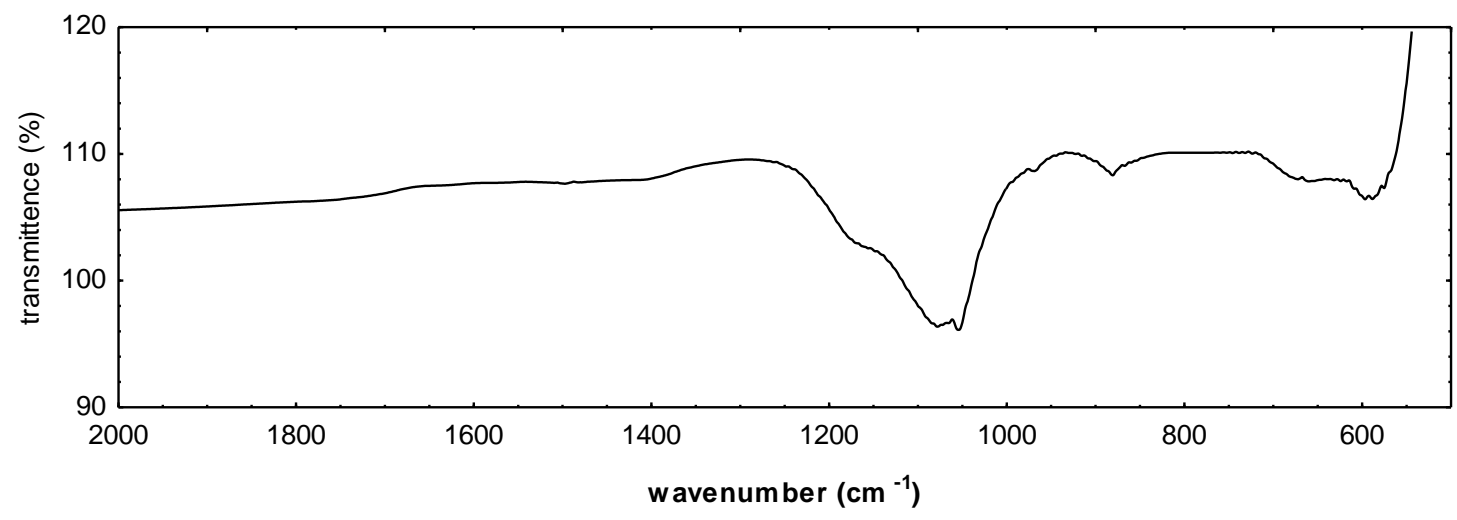




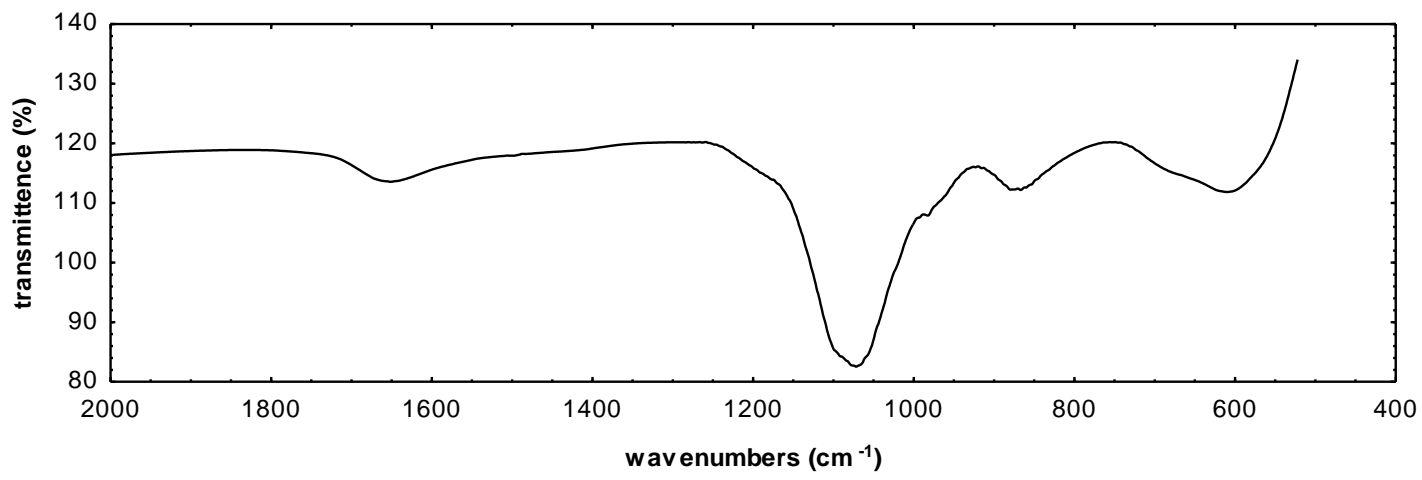

c)

Figure 11: FT-IR spectrum of chalcopyrite ore for $500^{\circ} \mathrm{C}(\mathrm{a}), 600^{\circ} \mathrm{C}(\mathrm{b})$ and $700^{\circ} \mathrm{C}$ (c)

\section{CONCLUSION}

This work was determined as the optimal roasting temperature $\left(500^{\circ} \mathrm{C}\right)$ and with sulfating roasting chalcopyrite concentrates for the recovery of copper. The phase transformations forms in chalcopyrite ore determined using thermal analysis techniques (TG/ DTG). The present study reported that $\mathrm{Cu}$-Fe-S transform into water-soluble sulphate phases at temperatures up to 700 and into oxides when the temperature is greater than $700^{\circ} \mathrm{C}$. The products of obtained roasted at selected temperatures for reaction and mechanism of roasting process were both characterized and supported by XRD, SEM/EDS, FTIR analysis

\section{REFERENCES}

Copur, M., Kızılca, M., Kocakerim, M.M. 2015, "Determination of the optimum conditions for copper leaching from chalcopyrite concentrate ore using taguchi method". Chemical Engineering Communications, vol. 202, no 7, 927-935.

Gulfen, M., Aydın, A.O. 2010, "Dissolution of copper from a primary chalcopyrite ore calcined with and without $\mathrm{Fe}_{2} \mathrm{O}_{3}$ in sulphuric acid solution", Indian Journal of Chemical Technology, vol. 17, 145-149.

Mikhlin, Y.L., Y.V. Tomashevich, Asanov, I. P., Okotrub, A.V., Varnek, V.A., Vyalikh, D.V. (2004). Spectroscopic and electrochemical characterization of the surface layers of chalcopyrite (CuFeS2) reacted in acidic solutions. Applied Surface Science, vol. 225,395-409.

Jain, R.C., Madhavan, S., Acharjee, D.K., Gupta Sen P. 1982," Optimum performance data for the leaching of roasted chalcopyrite concentrate in a jet contactor", The Canadian Journal of Chemical Engineering, vol. 60, 516-521.

Parasad, S., Pandey, B.D., 1998," Alternative processes for treatment of chalcopyrite -a review". Mineral Engineering, vol 11, no.8, 763781.

Parasad,S., Pandey,B.D., 1999. Thermoanalytical studies on copper-iron sulphides. Journal of Thermal Analysis and Calorimetry, vol. 58, 625-637.

Sargsyan, L.E., Hovhannisyan, A. M. 2010a, "Actived sulfating roasting of the chalcopyrite concentrate for sulfuric-acid leaching", Russian Journal of Non-Ferrous Metals, vol. 51, 386-388.

Sargsyan, L.E., Hovhannisyan, A. M. 2010b, "Investigation of chalcopyrite cuprum concentrate coasting by thermogravimetric and differential-thermal analysis", Metallurgical and Minning Industry, vol.2, no. 3, 225-229.

Sokić,M., Ilić, I., Źivković, D., Vućkovik N. 2008, "Investigation of mechanism and kinetics of chalcopyrite concentrate oxidation process". Metalurgija, vol. 47, 109-113.

Zhao Y., Hou Y., Cui Y., Liang H., Li L. 2015," Recovery of Copper from Copper Sulfide Concentrate by Sulfation Roasting". International Journal of Nonferrous Metallurgy, vol. 4, 9-13. 